\title{
Clinical Effect and Safety of Endoscopic Sinus Surgery in Patients over Seventy
}

\author{
Jung Hyeob Sohn and Kyoung Rai Cho \\ Department of Otorhinolaryngology-Head and Neck Surgery, Sanggye Paik Hospital, College of Medicine, Inje University, Seoul, Korea
}

\section{0세 이상 고령 환자에서 부비동 내시경 수술의 효과 및 안전성에 대한 연구}

\author{
손 정 협·조 경 래 \\ 인제대학교 의과대학 상계백병원 이비인후과학교실
}

\author{
Received July 9, 2018 \\ Revised August 17, 2018 \\ Accepted October 23, 2018 \\ Address for correspondence \\ Kyoung Rai Cho, MD, PhD \\ Department of Otorhinolaryngology- \\ Head and Neck Surgery, \\ Sanggye Paik Hospital, \\ College of Medicine, Inje University, \\ 1342 Dongil-ro, Nowon-gu, Seoul \\ 01757 , Korea \\ Tel $+82-2-950-1104$ \\ Fax $+82-2-935-6220$ \\ E-mail entr1@naver.com
}

Background and Objectives Chronic rhinosinusitis (CRS) is common in the elderly. There are increasing evidence that endoscopic sinus surgery (ESS) can be used to manage geriatric patients safely, although there are still concerns about complications after ESS. Therefore, the clinical effect and the safety of ESS in old patients was evaluated in the present study.

Subjects and Method Retrospective observational studies were performed based on medical records of patients over the age of 70 and who underwent ESS for CRS from January 2009 to December 2017. The clinical effect of ESS was assessed by comparing the sino-nasal outcome test (SNOT-22) scores before and 3 months after surgery. The safety of the operation was evaluated by the occurrence of postoperative major surgical (skull base, orbital and hemorrhage) and medical (ventricular fibrillation, ischemic attack, primary cardiac arrest, cerebrovascular accident, pneumonia, other organ failure and death) complications.

Results Seventy three subjects were enrolled in this study. Bilateral disease was observed in 37 cases $(50.7 \%)$, and CRS with nasal polyp was found in 31 cases $(42.5 \%)$. Eight patients $(11.0 \%)$ had revision cases. The majority $(93.2 \%)$ had at least one comorbid condition and got prescribed related medicine (87.7\%). There was a significant decrease in SNOT-22 score after surgery. Furthermore, there were no major surgical or medical complications except two cases with epistaxis.

Conclusion CRS in geriatric patients can also be treated effectively and safely by ESS as it is done for younger adults. However, as the incidence of comorbidities is high in elderly subjects, it is important to evaluate the risk factors preoperatively.

Korean J Otorhinolaryngol-Head Neck Surg 2019;62(2):95-101

Key Words Aged - Quality of life · Questionnaire · Safety · Nasal surgical procedures.

\section{서 론}

60세 이상에서 만성 비부비동염의 유병률은 $4.7 \%$ 로 드물 지 않으며, 노인 인구에서의 만성 질환에서 여섯 번째 흔한 질 환이라는 보고가 있다.,2) 고령에 따른 비부비동의 병태생리학

This is an Open Access article distributed under the terms of the Creative Commons Attribution Non-Commercial License (https://creativecommons.org/licenses/by-nc/4.0) which permits unrestricted non-commercial use, distribution, and reproduction in any medium, provided the original work is properly cited.
적인 변화와 관련 있는데, 1) 비점막의 탄력의 감소로 비강의 면적이 넓어지고, 2) 섬모 운동 능력의 감소로 비주기(nasal cycle)가 소실되며, 3) 코의 주변 구조를 지지해주는 섬유지 방조직(fibrofatty tissue)의 위축으로 비밸브(nasal valve)가 좁아져 코막힘이 악화되고, 4) 점액 분비선의 활성 증가로 점 성이 더 짙은 콧물의 발생이 증가하는 것으로 설명될 수 있 다." 고령의 환자에서 비용을 동반한 만성 비부비동염에 대 한 수술적 치료에 대해서는 젊은 환자 군과 비교했을 때 수 
술 전후 임상 증상의 호전 정도가 의미 있었다는 보고들이 있으며, 객관적인 수술 후 비내시경 소견에 있어서도 통계적 으로 유의하지는 않으나 젊은 환자 군보다 고령의 환자 군에 서 더 좋은 결과를 보여주었다는 보고가 있다.5) $\mathrm{Kim}$ 등은 비호산구성 용종(noneosinophilic nasal polyp)을 동반한 고 령의 만성 비부비동염에서 호중구(neutrophil)의 침윤 및 호 중구와 관련된 사이토 카인(cytokines)의 발현율이 낮아지 는 것이, 젊은 환자 군에서보다 더 나은 수술 경과를 보이는 것과 관련 있다는 보고를 하였다.

그러나 수술 후 임상 경과가 양호하다는 여러 연구 결과에 도 불구하고, 고령에 따른 수술의 위험성 때문에 수술 적응 증에 해당하더라도 적극적인 수술적 치료를 선택하지 않는 경향이 있을 수 있고,") 실제 과거 연구에서 젊은 환자 군에 비 해 고령 환자에서 부비동 내시경 수술의 합병증 빈도가 더 높 았다는 보고도 있다. ${ }^{89}$ 따라서 본 연구에서는 70세 이상의 고령 환자를 대상으로 만성 비부비동염의 임상 양상과 더불 어 부비동 내시경 수술 후 질환의 호전과 주요 합병증의 발 생 여부를 통해 수술의 효과와 안전성을 확인하고자 하였다.

\section{대상 및 방법}

\section{대 상}

임상시험심사위원회의 검토와 승인을 받은 후(승인번호: 2018-05-027), 2009년 1월부터 2017년 12월까지 본원에서 임상 증상과 비강 내시경 검사, 부비동의 전산화단층촬영 (CT)을 통해 만성 비부비동염으로 진단 받고 내시경 부비동 수술을 시행 받은 환자들 중에서 수술 시행 당시 연령이 만 70세 이상인 환자들의 의무 기록을 확인하였다. 만성 비부비 동염의 진단은 European Position Paper on Rhinosinusitis and Nasal Polyps 2012에 제시된 진단 기준에 합당한 경우 로 하였다. 내시경 부비동 수술은 근치적 목적으로 시행된 경 우를 대상으로 하여, 단순히 조직 검사를 목적으로 시행된 경 우는 본 연구에서 제외하였다. 반전성 유두종(inverted papilloma)을 포함한 비부비동의 종양, 침습성 진균 감염, 치성 낭, 상악동 근치술(Caldwell-Luc 수술) 후 발생한 술 후 상악 동 점액낭종(postoperative cheek cyst), 급성 비부비동염의 안 와 합병증 등으로 인한 비강 내시경을 통한 응급 배농에 대한 수술도 본 연구 대상에서 제외하였다.

\section{방 법}

의무 기록을 통해 환자의 연령과 성별, 비용(nasal polyp)의 유무와 병인에 따른 세부 진단, 음주 및 흡연 여부, Body Mass Index(BMI), 동반된 내과적 질환의 종류(심혈관계 질환, 내
분비계 질환, 뇌혈관계 질환, 기타 신경과 질환, 정신의학 질 환, 호흡기계 질환, 비뇨기계 질환, 신장 질환, 간 및 소화기계 질환, 암)와 이로 인해 수술 전후 복용 중인 약제의 종류, American Society of Anesthesiologists(ASA) physical status classification에 따라 수술 전에 평가한 위험도의 등급(등급 1 ; 전신 질환이 없는 경우, 등급 2; 잘 조절되는 경도의 전신 질환을 가진 경우, 등급 3 이상; 일상 생활에 제약을 주거나 생명을 위협할 정도의 중증 전신 질환을 가진 경우), 수술 전 CT 영상에 대해 Lund-Mackay 병기 판정법을 통해 판정한 질환의 중증도, sino-nasal outcome test(SNOT-22)를 통해 질환에 따른 삶의 질 척도, 부비동 내시경 수술의 과거력, 시 행된 수술의 범위와 소요 시간, 수술 후 재발 여부를 후향적 으로 확인하였다.

부비동 내시경 수술의 효과는 수술 전과 수술 후 3 개월에 시행된 SNOT-22 점수의 차이를 비교하여 주관적인 증상의 개선 여부를 통해 판단하였다. 수술의 안전성에 대해서는 수 술 후 합병증의 발생 여부를 통해 평가하였다. 수술 후 합병 증은 부비동 내시경 수술 자체의 합병증과 내과적 합병증으 로 분류하여 확인하였다. 수술 합병증은 International Classification of Diseases, Ninth Revision and current procedural terminology의 기준에 따라 ${ }^{10)}$ 두개저 합병증; 뇌척수 액 비루, 감염성 뇌수막염, 경막 파열과 안와 합병증; 복시 (dipolopia), 마비성 사시(paralytic strabismus), 시신경 손상, 실명, 유루증(epiphora), 안와 내 출혈과 이로 인한 안와 감 압술의 시행, 및 출혈; 비출혈, 내경동맥의 손상, 대량 출혈에 의한 수혈로 분류하였다. 내과적 합병증은 수술 이후 2주 내 에 발생한 심실 세동(ventricular fibrillation) 등 증상을 동반 한 부정맥, 협심증이나 심근 경색과 같은 허혈성 심질환, 심허 탈(heart failure)이나 심정지(primary cardiac arrest), 뇌혈관 질환(transient ischemic attack, cerebral or cerebellar infarction, subdural hemorrhage, subarachnoid hemorrhage, intracranial hemorrhage), 폐렴, 간과 신장 등의 장기 부전, 사 망의 발생 여부를 확인하였다.

\section{통계 분석}

SNOT-22를 통해 확인한 삶의 질 척도가 수술 전 비용의 동반 여부, 양측성 여부, 부비동 내시경 수술의 과거력 여부 에 따라 차이를 보이는 지 확인하기 위해 two-sample t test를 사용하였으며, 수술 전후 SNOT-22 점수의 차이가 유의한지 검정하기 위해 paired t test를 사용하였다. 이러한 통계 검정 은 Shapiro-Wilk test를 통해 정규성 검정을 하고 시행하였 다. 모든 통계 분석은 R package version 3.3.2(http://www. r-project.org)를 사용하였으며, 통계적 유의 수준은 $p<0.05$ 
로 하였다.

\section{결 과}

연구 대상이 된 환자는 73명(남: 43명, 여: 30 명)으로, 평균 연령은 74.1세(70 87세)였다. 양측성 비부비동염은 37명 (50.7\%), 일측성은 36 명 (49.3\%)이었으며, 비용을 동반한 경우 는 31명(42.5\%), 비용을 동반하지 않은 경우는 42명(57.5\%)이 었다. 비용을 동반하지 않는 경우 중에서는 23예(31.5\%)에서 진균구(fungus ball)가 확인되었고, 치과에서 임플란트를 시 행한 후 발병했거나 치과 시술 중 이물이 상악동 내로 들어간 경우, 치성 감염이나 발치로 인해 발생한 구강상악동누공 등 치과적 원인에 의한 경우는 7예(9.6\%)가 있었다.

수술 전 한가지 이상 동반 질환이 있었던 경우는 68명(93.2\%) 였으며, 심혈관계 질환, 내분비계 질환, 호흡기계 질환 순으로 빈도가 높았다(Table 1). 단일 질환으로는 고혈압(64.4\%)과 당 뇨(32.9\%)가 빈도가 높았으며, 고혈압과 당뇨를 동반한 경우 는 16예(21.9\%)였다. 동반 질환과 관련하여 64명(87.7\%)이 약 물을 복용하고 있었으며, 그 중 58명(79.5\%)이 2가지 이상의 약

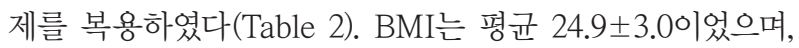
30 이상의 비만에 해당하는 경우는 3예(4.1\%)였다. 흡연의 과거 력이 있는 경우는 22명(30.1\%)였으나, 18예(24.7\%)에서는 수술 1 년 이전에 금연을 시행하여 수술 전후에 흡연 중인 경우는 4 예(5.5\%)였다. 음주의 경우 60예(82.2\%)에서는 술을 전혀 마 시지 않는다고 하였으며, 월 10회 이상 음주를 즐기는 경우는 나머지 13예(17.8\%) 중 7예(9.6\%)에서 해당하였다. 또한 음주

Table 1. Distribution of coexisting disease

\begin{tabular}{lc}
\hline \multicolumn{1}{c}{ Variable } & No. of patients (\%) \\
\hline Cardiovascular disease & $55(75.3)$ \\
Hypertension & $47(64.4)$ \\
Congestive heart failure & $1(1.4)$ \\
Ischemic heart disease & $13(17.8)$ \\
Arrhythmia & $2(2.7)$ \\
Endocrine disease & $26(35.6)$ \\
Diabetes mellitus & $24(32.9)$ \\
Thyroid disease & $3(4.1)$ \\
Cerebrovascular disease & $7(9.6)$ \\
Other neurologic disease & $2(2.7)$ \\
Psychiatric disease & $5(6.8)$ \\
Respiratory disease & $10(13.7)$ \\
Renal disease & $1(1.4)$ \\
Hepato-gastroenterologic disease & $4(5.5)$ \\
Urologic disease & $8(11.0)$ \\
Previous cancer & $5(6.8)$
\end{tabular}

Some patients had more than one type of disease. Sixteen patients had both hypertension and diabetes mellitus
와 흡연의 과거력이 있는 경우는 모두 남자 환자였다. ASA physical status classification의 기준에 의하면 등급 1 과 2에 해당하는 경우가 각각 3 명(4.1\%), 57명(78.1\%)이었고, 3 이상에 해당하는 환자는 13명(17.8\%)이었다.

수술 전 CT 영상으로 확인한 Lund-Mackay 점수는 양측 성 비부비동염에서 $15.0 \pm 3.54$ 로, 그 중 비용을 동반한 경우 에서는 $16.9 \pm 2.89$ 로 확인되었으며, 일측성 비부비동염에서는 $6.46 \pm 2.24$ 로 확인되었다. 수술 전 확인한 SNOT-22 점수는 $28.6 \pm 8.87$ 이었으며, 비용을 동반한 경우와 비용을 동반하지 않은 경우에서의 점수는 각각 $34.8 \pm 8.61$ 과 $22.8 \pm 6.68$ 이었다. 양측성과 일측성에서는 SNOT-22 점수가 $33.8 \pm .57$ 과 $23.2 \pm$ 7.37로 나타났으며, 초수술과 재수술인 경우에는 28.3 \pm 8.91 과 $31.1 \pm 8.38$ 로 확인되었다. 비용의 동반 여부와 양측성 여부 는 수술 전 SNOT-22 점수와 관련이 있는 것으로 확인되었으 며 $(p<0.01)$, 재수술 여부에 따른 점수 차이는 유의하지 않았 다 $(p=0.96)$.

부비동 내시경 수술은 68명(93.2\%)에서 전신마취 하에 수술 을 진행하였고, 나머지 5명(6.8\%)은 국소마취로 수술을 시행 하였다. 과거 부비동 내시경 수술을 시행받은 경우는 8예 (11.0\%)였다. 수술의 범위는 수술 전 시행한 CT와 수술 당시 비강 내시경 소견에 따라 결정되었으며, 39예(53.4\%)에서 전 사골동과 상악동에 대한 수술만 시행되었고 34예(46.6\%)는 전두동이나 접형동이 수술 범위에 포함되었다. 수술 시간은 $89.1 \pm 19.0$ 분이 소요되었다. 항응고제(antiplatelet agent)나 항 혈전제(anticoagulant)의 복용 여부에 따라 수술 소요 시간을 확인했을 때 항응고제나 항혈전제를 사용했던 경우에서 85.6 \pm 19.6 분으로, 사용하지 않았던 경우에서 $91.7 \pm 18.3$ 분이 소요 된 것과 비교했을 때 오히려 유의하게 수술 시간이 짧게 소

Table 2. List of prescribed medicine for coexisting disease

\begin{tabular}{lc}
\hline \multicolumn{1}{c}{ Type of medicine } & No. of patients (\%) \\
\hline Anti-hypertensive: multi/single & $38(52.1) / 16(21.9)$ \\
Beta-blocker & $15(20.5)$ \\
Calcium channel blocker & $19(26.0)$ \\
ACE-l/Angiotensin II receptor blocker & $28(38.4)$ \\
Anti-hyperlipidemic agent & $22(30.1)$ \\
Hypoglycemic agent: multi/single & $11(15.1) / 7(9.6)$ \\
Anti-thrombotic angent & $31(42.5)$ \\
Anti-coagulants: warfarin & $3(4.1)$ \\
Aspirin & $18(24.7)$ \\
Clopidogrel & $6(8.2)$ \\
Aspirin+clopidogrel & $4(5.5)$ \\
Psychiatric agent & $11(15.1)$ \\
Anti-convulsant agent & $1(1.4)$ \\
Others & $12(16.4)$ \\
\hline ACE-l:Angiogensin
\end{tabular}

ACE-I: Angiogensin-converting enzyme inhibitor 
요된 것으로 나타났다 $(p<0.01)$. 다만 비용종을 동반한 양측 성 비부비동염의 경우를 비교했을 때에는 항응고제나 항혈 전제를 사용했던 경우와 그렇지 않은 경우의 수술 시간이 각

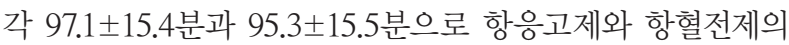
사용 여부가 수술 시간의 증가와 관련이 있는 것으로 확인되

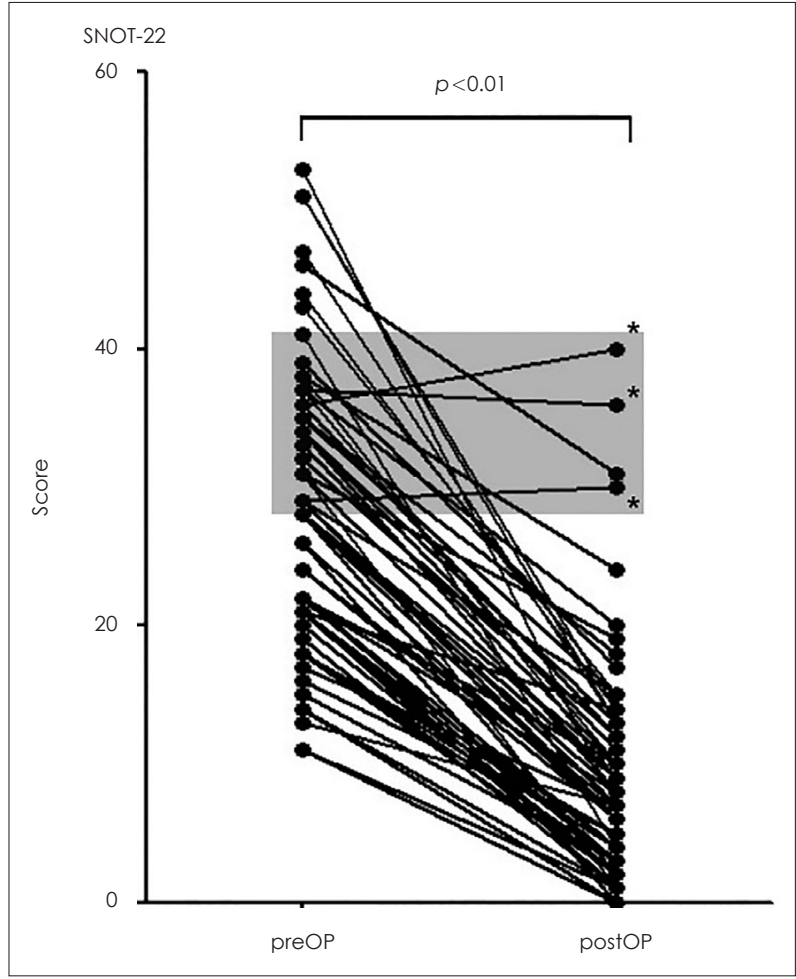

Fig. 1. Changes of SNOT-22 score before and 3 months after surgery in 63 subjects, who were able to follow up 3 months postoperatively: most of the subjects, except 3 of 63 cases $(*)$, show a statistically significant decrease in their scores $(p<0.01)$. OP: operation, SNOT-22: sino-nasal outcome test.
었다 $(p<0.01)$.

수술 중 뇌척수액 비루나 경막 파열이 확인된 경우는 없었 으며, 수술 이후 감염성 뇌수막염이 발생한 경우도 없었다. 안 와 합병증이 발생한 경우도 전혀 없었다. 수술 후 비출혈이 발 생하여 응급실에 내원한 경우가 2예(2.7\%)였으며, 두 경우 모 두 큰 어려움 없이 지혈되었다. 수술 중 대량 출혈이나 수술 후에 발생한 비출혈로 인해 수혈을 필요로 했던 경우는 없었 다. 수술 시행 후 2주 이내에 부정맥, 허혈성 심질환, 심허탈 이나 심정지, 뇌혈관 질환, 폐렴, 기타 장기 부전이나 사망 등 내과적 합병증의 발생도 전혀 없었다. 수술 후 7 개월과 1 년 7 개월 후에 각각 일과성 허혈 발작(transient ischemic attack) 과 자발성 지주막 하 출혈(spontaneous subarachnoid hemorrhage)이 발생하여 본원에서 입원 치료를 시행 받은 경우 가 2예 있었으나, 뇌혈관 질환의 발생 시점과 부비동 내시경 수술 사이의 시간 차이가 커서 수술과 직접 관련은 없다고 판 단된다.

전제 환자 중에서 수술 후 3 개월까지 외래 추적 관찰이 가 능했던 63명(86.3\%)의 환자를 대상으로 수술 후 3개월에 시 행한 SNOT-22 점수를 수술 전과 비교하였으며, 60명(60/63, 95.2\%)의 환자가 주관적인 삶의 질의 호전을 보였다(Fig. 1). 점수의 차이는 $19.1 \pm 6.6$ 이었으며, 비용을 동반한 경우와 동 반하지 않는 경우는 $22.4 \pm 6.6$ 과 $16.7 \pm 5.7$ 이었다. 양측성과 일측성에서는 수술 전후 SNOT-22 점수의 차이가 $19.8 \pm 7.12$ 와 $18.3 \pm 5.83$ 으로 나타났으며, 초수술과 재수술인 경우에는 각각 $19.5 \pm 6.54$ 와 $15.2 \pm 8.11$ 로 확인되었다(Fig. 2). 비용의 동반, 양측성 여부, 재수술 여부와 상관없이 수술 전과 수술 후 3개월에 확인한 SNOT-22 점수의 차이는 통계적으로 유 의한 것으로 확인되었다 $(p<0.02)$. 7 예(7/63, $11.1 \%)$ 에서 수술

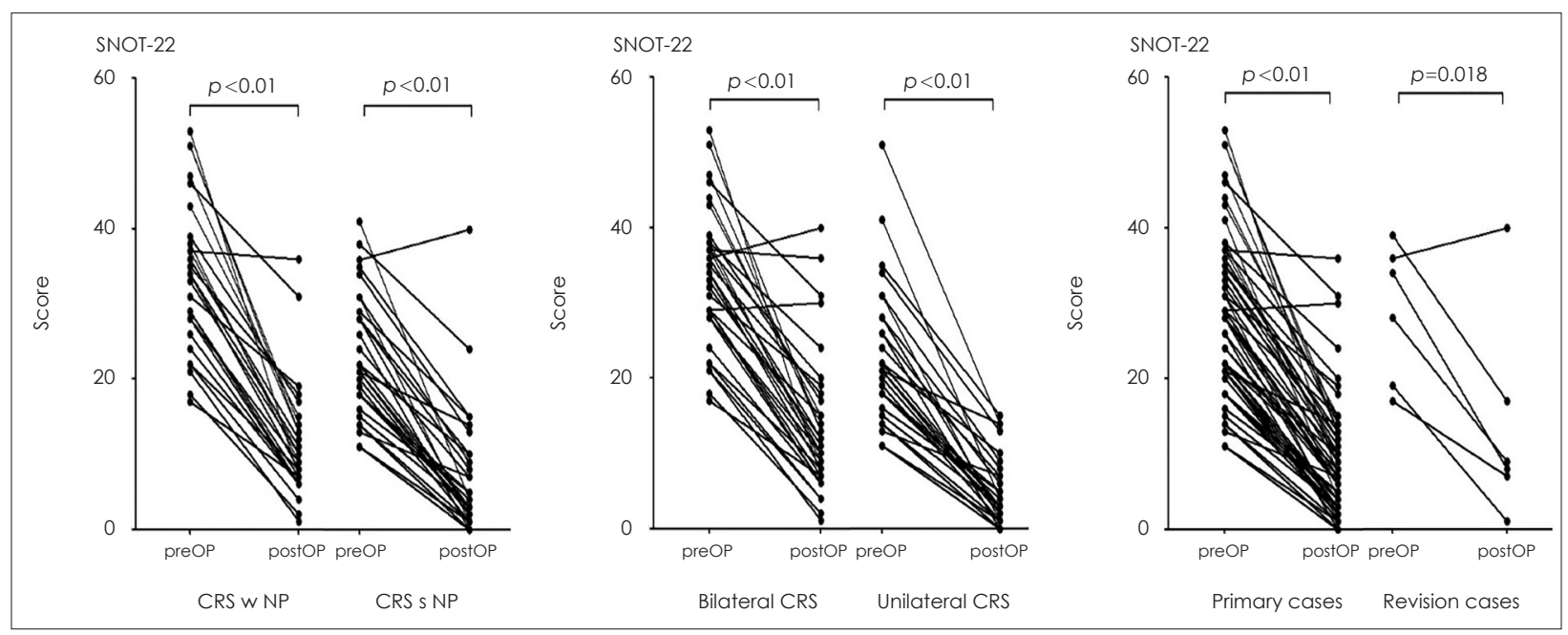

Fig. 2. Changes of SNOT-22 score before and 3 months after surgery were categorized according to the presence of nasal polyp, bilaterality and primary versus revision: the perioperative changes of SNOT-22 score are significant in all criteria $(p<0.02)$. CRS: chronic rhinosinusitis, OP: operation, NP: nasal polyp, SNOT-22: sino-nasal outcome test. 
후 재발을 확인하였으며, 이 중에서 2예(2/63, 3.2\%)에서 재수 술이 시행되었다.

\section{고 찰}

나이가 증가함에 따라 수술의 위험도는 증가한다고 알려 져 있으며,11) 특히 70세 이상에서 현저하다는 보고가 있다. ${ }^{12)}$ 고령의 환자에서 수술에 따른 사망률과 이환율의 증가는 노 화 자체가 독립적인 위험 요소이지만,1) 동반하고 있는 다양 환 질환과 이로 인해 함께 복용하는 약제와도 관련이 있다. ${ }^{13)}$ Turrentine 등 ${ }^{22)}$ 은 수술 전 고혈압과 호흡 곤란 증상이 있었 던 경우, 수술 전 수혈을 받거나 체중 감소가 있었던 경우, 응 급 수술인 경우가 고령에서 수술 위험도를 증가시킬 수 있는 위험 요소이며, 수술 시간과 ASA physical status classification에 따른 신체상태분류는 전 연령에서 수술 위험도와 관 련 있는 요소라고 하였다.

본 연구에서는 부비동 내시경 수술을 시행받은 70세 이상 의 환자들 중 대부분이(93.2\%) 한 가지 이상의 동반 질환을 가지고 있었으며, 다수에서(79.5\%) 여러 종류의 약제를 복용 하고 있었다. 가장 사용 빈도가 높은(64.4\%) 항고혈압 약제의 경우 약제 간 상호 작용이나, 전신 마취에서 사용하는 약제들 과 상호 작용으로 인해 서맥(bradycardia)이나 혈압의 저하, 심 부전 등의 문제를 일으키는 경우도 있다고 알려져 있다. ${ }^{13)}$ 안 지오텐신 전환 효소 억제제(angiotensin converting enzyme inhibitor)나 안지오텐신 II 수용체 차단제(angiotensin II receptor blocker)의 경우 기관 삽관 후 즉각적인 혈압의 저하 를 유발할 수 있고, ${ }^{14)}$ 베타 차단제(beta-blocker)는 프로포폴 (propofol)과 상호 작용으로 심한 서맥이나 심정지를 유발할 수 있으며, ${ }^{15)}$ 칼슘 통로 차단제(calcium channel blocker)는 베타 차단제와 상호 작용으로 심한 서맥이 발생할 수 있다고 한다. ${ }^{16)}$ 다만 이러한 상호 작용을 고려하여 평소에 사용 중이 었던 항고혈압 약제를 수술 전후에 중단하는 것은 권유되지 않는다. ${ }^{13)}$ 본 연구에서는 수술 중 출혈 경향을 증가시킬 수 있 는 항응고제와 항혈전제의 사용 빈도도 적지 않았다(42.5\%). 수술 전후 항응고제나 항혈전제의 중단에 대해서는 명확한 기준이 없다. 일반적으로 수술 1주 전부터 수술 이후 출혈의 위험성이 현저하게 감소하는 시기까지 투약을 중단하는 것 으로 알려져 있으며, 본 연구에서는 수술 1주 전부터 수술 2 일 후까지 항응고제나 항혈전제를 중단하였다. Devereaux 등 ${ }^{17)}$ 은 비심장 수술(noncardiac surgery)에서 수술 전후 아스 피린(aspirin)의 사용이 사망률이나 심근 경색의 위험도를 감 소시키지 못하고 오히려 수술 중 출혈의 위험도를 증가시킨 다고 하였다. 하지만 Columbo 등 ${ }^{18)}$ 은 항응고제의 투여가 필
요한 환자의 비심장 수술에서 항응고제를 유지하는 것이 오히 려 더 안전하다고 하였다. 경피적 관상동맥 중재술(percutaneous coronary intervention)을 시행받은 병력이 있는 환자 의 경우 비심장 수술에서 아스피린을 유지하는 것이 출혈 경 향의 증가와 항응고제의 사용에 따른 사망률이나 심근 경색 의 발생 빈도 감소를 비교했을 때 더 이득이 크다는 보고도 있었다. ${ }^{19)}$ 본 연구에서는 항응고제나 항혈전제의 사용에 따 른 수술 소요 시간의 차이를 확인하였는데, 오히려 항응고제 나 항혈전제를 사용했던 경우에서 수술 소요 시간이 더 짧은 것으로 나타났다. 다만 비용종을 동반한 양측성 비부비동염 의 경우에는 수술 전 항응고제나 항혈전제의 사용 여부가 수술 시간의 증가와 관련이 있는 것으로 확인되었다. 소화기 내시경을 통해 시행되는 시술의 경우에는 출혈 위험도에 따 라 고위험군과 저위험군으로 분류하여 시술 전후 항응고제 나 항혈전제의 유지 여부를 결정하는 시도가 있었다. ${ }^{20)}$ 부비 동 내시경 수술의 경우 비강이 좁고 해부학적 구조가 복잡 하여 대량 출혈이 발생할 경우 수술 시야를 확보하기 어렵고, 안와나 뇌 기저부의 손상 위험성이 있어 항응고제나 항혈전 제를 수술 전후에 중단하는 것이 바람직하겠으나, 심혈관계 질환을 동반한 고령의 환자에서는 부비동 내시경 수술을 시 행할 때 비부비동염의 심한 정도와 수술 범위 등을 고려하여 수술 중 항응고제와 항혈전제의 유지 여부에 따른 이득과 위 험도를 평가하는 연구가 필요하다고 생각된다. 우리 나라의 경우 한약(herbal medication)의 빈도가 높다는 점도 고려해 야 한다. 마늘(garlic)의 섭취는 출혈 경향을 증가 시킬 수 있 다고 하며, 한약제에서 사용 빈도가 높은 마황(ephedra)은 수술 중 심근 경색이나 허혈성 뇌혈관 질환의 위험성을 증가 시킬 수 있다고 한다. 인삼(ginseng)도 혈당을 낮추는 효과가 있으며, 수술 중 출혈 경향을 증가시킬 수 있다는 보고가 있 어 주의가 필요하다. ${ }^{21)}$

저혈압 마취(hypotensive anesthesia)가 부비동 내시경 수 술에서 출혈을 의미 있게 감소시켜 수술 시야의 개선에 도움 을 주는 것으로 알려져 있으며, 건강한 정상 성인의 경우 평 균 동맥압(mean arterial pressure, MAP)을 $60 \mathrm{~mm} \mathrm{Hg}$ 이 상으로 유지하면 안전하다는 보고가 있었다. ${ }^{22)}$ 그러나 고령 의 환자, 특이 심혈관계 질환의 과거력을 가지고 있는 환자의 경우에서는 저혈압 마취를 시행하고자 할 때 안전한 MAP 범 위에 대한 연구가 없으며, 기존에 복용 중인 약제가 혈압에 영 향을 줄 수 있어 수술 중 적절한 마취 심도를 유지하는 데 어 려움이 있다.

본 연구의 경우 70세 이상의 환자에서 부비동 내시경 수술 을 시행한 후 내과적 합병증은 전혀 나타나지 않은 것으로 나 타났다. 대상이 된 환자들에서 동반 질환이나 항혈전제나 항 
응고제의 사용 빈도가 낮지 않고, 수술 전 CT 영상을 통해 확 인한 Lund-Mackay 점수나 SNOT-22 점수를 통해 확인한 삶의 질 척도도 비교적 높았으며, 절반 정도의(46.6\%) 환자에 서 접형동이나 전두동이 수술 범위에 포함되어 있어, 연구 대 상 선정의 편향성으로 결과가 과소 평가되었을 가능성은 높 지 않다고 판단된다. 다만 연구 대상에서 $\mathrm{BMI}$ 의 평균이 24.9 \pm 3.0 으로 비만의 빈도가 높지 않고(4.1\%), 흡연이나 음주를 즐기는 빈도도 낮은 점을 고려했을 때, 70세 이상에서 부비 동 내시경 수술을 비응급으로 시행 받는 환자들은 비록 동 반 질환을 갖고 있더라도 건강에 대한 관심이 높고 건강을 지키기 위한 노력을 유지하는 경우가 많다고 가정해 볼 수 있겠다. 따라서 70 세 이상의 고령 환자에서 부비동 내시경 수술의 위험도를 정확하게 확인하기 위해서는, 만성 부비동 염으로 수술이 필요하다고 판단되는 환자들에서 실제 수술이 시행된 경우와 그렇지 못한 경우를 모두 포함하여 전향적으 로 연구하는 것이 필요하겠다. 본원에서는 수술이 필요한 환 자에서 내과적 질환의 과거력를 포함하여 주요 심혈관계 합병 증을 예측할 수 있는 위험 인자를 확인하여(revised cardiac risk index ${ }^{23)}$ 내과 협진을 진행하며, 심장 내과의 경우 심장 기능 분류(cardiac functional status)를 고려하여 ${ }^{24)}$ 경흥부 심 초음파 검사 등의 추가 검사를 시행하여 수술 가능 여부 및 위험도를 평가하고 있다. 수술 시간도 수술 위험도에 영향을 주는 주요 요소인데, ${ }^{12)}$ 부비동 내시경 수술은 술기에 익숙한 비과 의사에 의해 시행될 경우 정형외과나 외과에서 시행되 는 주요 수술에 비해 비교적 빠른 시간에 이루어질 수 있어 수술의 위험도가 상대적으로 낮다고 판단되며, 본 연구에서 도 평균 수술 시간은 89.1 19.0 분으로 확인되었다.

수술 합병증의 경우 Ramadan 등은 65 세 이상의 환자에 서 그보다 젊은 환자군과 비교했을 때 부비동 내시경 수술의 합병증이 높다고(21.7\% vs. $12.8 \%$ ) 하였다. Jiang 등9)도 65세 이상의 환자에서 젊은 환자군과 비교했을 때, 수술 결과는 유사했으나 합병증의 빈도는 더 높았다고(15.2\% vs. 9.5\%) 보고하였다. 본 연구는 연령 별 대조군을 설정하지 않은 관 찰 연구라는 한계가 있으나, 이전의 두 연구와 비교했을 때 수 술 합병증의 빈도가 매우 낮아(2.7\%) 의미가 있다고 생각된 다. 이전 연구가 2001년과 2004년에 시행되어, 그 동안 부비동 내시경 수술의 술기가 크게 발전되었다고 추정해볼 수도 있 겠다. 하지만 저자들은 수술 합병증의 경우 연령 자체보다는 비부비동의 해부학적 구조의 복잡성, 재수술 여부, 동반된 비 용의 심한 정도, 수술 중 출혈량이 좀 더 관련 높은 위험 요소 라고 판단하여, 향후 이러한 요소들을 고려한 연령 별 대조군 연구가 필요하다고 생각한다.

고령에서의 부비동 내시경 수술은 상대적으로 재발률이
낮고 젊은 환자군과 비교했을 때 유의하게 좋은 결과를 보이 는 것으로 알려져 있으며, ${ }^{3)}$ 본 연구에서도 대부분의 경우에서 수술 후 주관적 삶의 질 척도의 호전을 보였다. Alakärppä 등 25 은 평균 연령이 39세(28 50세)이고 부비동 내시경 수술을 시 행받은 84명의 환자를 대상으로 시행한 연구에서 수술 전과 수술 후 12 개월에 시행한 SNOT-22 점수는 각각 $35.1 \pm 19.2$ 와 $19.3 \pm 14.3$ 으로 평균 18.0점의 호전을 보고한 바 있다. 부비 동 내시경 수술을 시행 받은 18 세 이상의 122 명의 환자에 대 한 연구에서도 수술 전과 수술 후 6개월의 SNOT-22 점수는 각각 51.8(48.7 55.0)과 33.0(29.2 36.8)로 나타났다. ${ }^{26)}$ 추적 관찰 기간의 차이는 있으나 본 연구에서 확인된 70세 이상 고 령 환자들의 수술 전후 증상 개선 정도는 청장년층을 대상으 로 한 다른 연구에서의 결과와 큰 차이가 없음을 확인할 수 있었다. 호전이 없었던 3예에서, 1 예의 경우 호전되지 않는 우 측 안면통을 주소로 내원한 환자에서 수술 전 CT 영상을 시 행하여 좌측 상악동 내부의 진균구와 우측 상악동 내의 단 순 연부조직 음영이 확인되었던 경우였다. 증상과 영상 소견 이 일치하지 않았으나, 환자가 강력히 수술을 원하였고 양측 모두 만성 비부비동염 소견이 있어 양측 부비동 내시경 수술 이 시행되었으며, 우측 안면통은 호전되지 않았다. 나머지 2예 의 경우 Child-Pugh class B의 간경화증을 가지고 있으며 비 용을 동반한 양측 비부비동염 환자에서 수술 후 부비동염이 주기적으로 재발하는 경우와, 비용을 동반하지 않은 일측성 비부비동염에서 수술 후 비내시경 소견은 양호하였으나 후비 루감을 지속적으로 호소하는 경우였다.

만성 비부비동염은 고령에서도 빈도가 높고 삶의 질에 많 은 영향을 주는 질환으로, 항생제나 비강 세척, 국소 스테로 이드의 충분한 투여에도 반응을 보이지 않는다면 부비동 내 시경 수술이 도움이 될 수 있다. 고령에서는 동반 질환의 빈 도가 높고 이로 인해 함께 복용 중인 약물이 많아, 수술에 영 향을 줄 수 있는 위험 요소에 대해 수술 전에 충분히 평가하 는 것이 중요하겠다. 수술 합병증이 단순히 고령 환자에서 젊 은 환자들에 비해 높은 것은 아니라고 판단되며, 이에 대해 서는 재수술 여부, 해부학적 구조의 복잡성, 전신 상태, 질환 자체의 심한 정도, 비용의 존재와 호산구성 용종 여부 및 수 술 중 출혈량과 같은 요소들을 고려한 연령군별 전향적인 대 조 연구가 필요하다고 생각된다.

\section{REFERENCES}

1) Chen $Y$, Dales R, Lin M. The epidemiology of chronic rhinosinusitis in Canadians. Laryngoscope 2003;113(7):1199-205.

2) Fokkens WJ, Lund VJ, Mullol J, Bachert C, Alobid I, Baroody F, et al. European position paper on rhinosinusitis and nasal polyps 2012. Rhinol Suppl 2012;23:3.

3) Marioni G, Zanotti C, Brescia G. Chronic rhinosinusitis with nasal 
polyps in the elderly: assessing current evidence. Allergy Asthma Proc 2018;39(1):9-13.

4) Lee JY, Lee SW. Influence of age on the surgical outcome after endoscopic sinus surgery for chronic rhinosinusitis with nasal polyposis. Laryngoscope 2007;117(6):1084-9.

5) Shin JM, Byun JY, Baek BJ, Lee JY. Cellular proliferation and angiogenesis in nasal polyps of young adult and geriatric patients. Int Forum Allergy Rhinol 2015;5(6):541-6.

6) Kim DW, Kim DK, Jo A, Jin HR, Eun KM, Mo JH, et al. Agerelated decline of neutrophilic inflammation is associated with better postoperative prognosis in non-eosinophilic nasal polyps. PLoS One 2016;11(2):e0148442.

7) Wanebo HJ, Cole B, Chung M, Vezeridis M, Schepps B, Fulton J, et al. Is surgical management compromised in elderly patients with breast cancer? Ann Surg 1997;225(5):579-86; discussion 586-9.

8) Ramadan HH, VanMetre R. Endoscopic sinus surgery in geriatric population. Am J Rhinol 2004;18(2):125-7.

9) Jiang RS, Hsu CY. Endoscopic sinus surgery for the treatment of chronic sinusitis in geriatric patients. Ear Nose Throat J 2001;80(4):230-2.

10) Krings JG, Kallogjeri D, Wineland A, Nepple KG, Piccirillo JF, Getz AE. Complications of primary and revision functional endoscopic sinus surgery for chronic rhinosinusitis. Laryngoscope 2014;124(4): $838-45$.

11) Rooke GA. Cardiovascular aging and anesthetic implications. J Cardiothorac Vasc Anesth 2003;17(4):512-23.

12) Turrentine FE, Wang H, Simpson VB, Jones RS. Surgical risk factors, morbidity, and mortality in elderly patients. J Am Coll Surg 2006;203(6):865-77.

13) Das S, Forrest K, Howell S. General anaesthesia in elderly patients with cardiovascular disorders: choice of anaesthetic agent. Drugs Aging 2010;27(4):265-82.

14) Comfere T, Sprung J, Kumar MM, Draper M, Wilson DP, Williams $\mathrm{BA}$, et al. Angiotensin system inhibitors in a general surgical population. Anesth Analg 2005;100(3):636-44.

15) Hayashi Y, Sumikawa K, Kuro M, Fukumitsu K, Tashiro C, Yoshiya I. Roles of beta 1- and beta 2- adrenoceptors in the mechanism of halothane myocardial sensitization in dogs. Anesth Analg 1991;72 (4):435-9.

16) Wood M. Pharmacokinetic drug interactions in anaesthetic practice. Clin Pharmacokinet 1991;21(4):285-307.
17) Devereaux PJ, Mrkobrada M, Sessler DI, Leslie K, Alonso-Coello $\mathrm{P}$, Kurz A, et al. Aspirin in patients undergoing noncardiac surgery. N Engl J Med 2014;370(16):1494-503.

18) Columbo JA, Lambour AJ, Sundling RA, Chauhan NB, Bessen SY, Linshaw DL, et al. A meta-analysis of the impact of aspirin, clopidogrel, and dual antiplatelet therapy on bleeding complications in noncardiac surgery. Ann Surg 2018;267(1):1-10.

19) Graham MM, Sessler DI, Parlow JL, Biccard BM, Guyatt G, Leslie $\mathrm{K}$, et al. Aspirin in patients with previous percutaneous coronary intervention undergoing noncardiac surgery. Ann Intern Med 2018; 168(4):237-44.

20) ASGE Standards of Practice Committee; Anderson MA, BenMenachem T, Gan SI, Appalaneni V, Banerjee S, Cash BD, et al. Management of antithrombotic agents for endoscopic procedures. Gastrointest Endosc 2009;70(6):1060-70.

21) Ang-Lee MK, Moss J, Yuan CS. Herbal medicines and perioperative care. JAMA 2001;286(2):208-16.

22) Ha TN, van Renen RG, Ludbrook GL, Valentine R, Ou J, Wormald PJ. The relationship between hypotension, cerebral flow, and the surgical field during endoscopic sinus surgery. Laryngoscope 2014; 124(10):2224-30

23) Devereaux PJ, Goldman L, Yusuf S, Gilbert K, Leslie K, Guyatt GH. Surveillance and prevention of major perioperative ischemic cardiac events in patients undergoing noncardiac surgery: a review. CMAJ 2005;173(7):779-88.

24) Eagle KA, Berger PB, Calkins H, Chaitman BR, Ewy GA, Fleischmann KE, et al. ACC/AHA guideline update for perioperative cardiovascular evaluation for noncardiac surgery--executive summary: a report of the American College of Cardiology/American Heart Association Task Force on Practice Guidelines (Committee to Update the 1996 Guidelines on Perioperative Cardiovascular Evaluation for Noncardiac Surgery). J Am Coll Cardiol 2002;39(3):542-53.

25) Alakärppä AI, Koskenkorva TJ, Koivunen PT, Alho OP. Quality of life before and after sinonasal surgery: a population-based matched cohort study. Eur Arch Otorhinolaryngol 2017;274(2):795-802.

26) Sahlstrand-Johnson P, Hopkins C, Ohlsson B, Ahlner-Elmqvist M. The effect of endoscopic sinus surgery on quality of life and absenteeism in patients with chronic rhinosinuitis - a multi-centre study. Rhinology 2017;55(3):251-61. 